\title{
BIG DATA AND ASSOCIATED SKILLS: SYSTEMATIC OVERVIEW
}

\author{
Atis Verdenhofs ${ }^{1}, M_{B A}$; Tatjana Tambovceva ${ }^{2}$, Dr.oec / Professor
}

${ }_{1,2}$ Riga Technical University

\begin{abstract}
Technological development is causing increase of data available for organizations. Not only amount of data but also areas of application in organizations are increasing. However, this change is also bringing certain challenges - starting with storage of data and ending with analysis and interpretation of data to benefit from it. This research is aimed to identify skills and competences needed to operate with big data. Research question is what type of skills or competences are needed to be able to use big data solutions. Research object is big data solutions, research subject - skills or competences needed for big data solutions.

To identify needed skills and competences systematic literature overview is performed. Detailed description of research article selection is described. Scopus database is used for research article selection. After reviewing selected research articles, authors identify skills or competences in each. Afterwards most mentioned and more often identified skills are summarized. Main skills and competences that authors identified in the research are connected with three main areas - analytical, technological and managerial fields. Communication skills are mentioned as crucial to benefit from big data solutions since it requires cooperation and mutual understanding from different departments of organization.
\end{abstract}

Key words: literature overview, big data, skills, competences.

JEL code: 015,033

\section{Introduction}

Technological development is causing increase of data available for organizations. Not only amount of data but also areas of application of the data are increasing in organizations. However, this change is also bringing certain challenges - starting with storage of data and ending with analysis and interpretation of data to benefit from it. Also employees with skills and competences that allow organizations to benefit from big data are becoming more required.

Professional organizations almost decade ago indicated that big data will have an increasing importance in business and that there will be lack of talent that will be able to work with big data (McKinsey Global Institute, 2011). The aim of this research is to identify skills and competences needed in organization to operate with big data.

Research question is what type of skills or competences are needed in organization to utilize big data. Research object is big data and research subject is skills and competences needed to operate with big data. To identify needed skills and competences systematic literature overview were performed; keywords and source for literature search were defined, selected publications were analysed, skills and competences were identified and grouped.

Organizations that want to become more efficient by utilizing big data will need to cover identified list of skills and competences. This is possible by identifying skills and competences among existing workforce or training existing employees or hiring new employees that have needed skills and competences.

\section{Methodology of research}

Literature review that is performed in systematic approach should be precise and one should be able to reproduce the review (Booth A. et al, 2012). Therefore, authors of this research are providing explicit details of search strategy. Search of literature for this research paper was performed in November and December 2017. Database used for search - SCOPUS. 


\section{Selection of research papers}

First step is usage of keyword "big data" in SCOPUS database, for which 38281 results are shown in database. In the second step, additional keywords are added - "skill*" and "competence". Keywords are added in a manner so that one or another in combination with "big data" would give a positive hit. Also keyword "skill" has a form that would hit both singular and plural form of word. After second step there are 602 results left.

Third step is to limit results to specific type of research - only articles. It is done with aim to have more quality research papers that have gone through peer review and have been published. After third step there are 226 results left.

Fourth step is to limit results only to one area "Business, Management and Accounting". It is done to exclude specific area research papers that are dealing with sector specific questions. Since area of research is very closely connected with Information Technology (IT), then vast majority of articles are connected with evaluation of different technical solutions or statistical methods connected with big data and not business management related areas. After fourth step there are 50 results left.

Table 1

Article selection criteria

\begin{tabular}{|c|c|c|c|c|}
\hline $\begin{array}{l}\text { Step } \\
\text { no. }\end{array}$ & Criteria & Reason & $\begin{array}{l}\text { Criteria in SCOPUS } \\
\text { search syntax }\end{array}$ & $\begin{array}{c}\text { Number } \\
\text { of } \\
\text { results }\end{array}$ \\
\hline 1 & Keyword 1 & $\begin{array}{l}\text { Main keyword for identifying area of } \\
\text { interest }\end{array}$ & "big data" & $n=38281$ \\
\hline 2 & Keyword 2 & $\begin{array}{l}\text { Additional keywords for targeting } \\
\text { researches }\end{array}$ & $\begin{array}{l}\text { AND ("skill*" OR } \\
\text { „competence") }\end{array}$ & $n=602$ \\
\hline 3 & $\begin{array}{l}\text { Limit to } \\
\text { document type } \\
\text { "Article" }\end{array}$ & $\begin{array}{l}\text { Limiting to research types that have } \\
\text { passed reviews for publications }\end{array}$ & $\begin{array}{l}\text { AND (LIMIT-TO } \\
(\text { DOCTYPE, "ar")) }\end{array}$ & $n=226$ \\
\hline 4 & $\begin{array}{l}\text { Limit to } \\
\text { subject area } \\
\text { "Business, } \\
\text { Management } \\
\text { and } \\
\text { Accounting" }\end{array}$ & $\begin{array}{l}\text { Limiting to area that is connected with } \\
\text { organizations and management and that } \\
\text { are not connected with specific fields of } \\
\text { research like medicine, computer sciences } \\
\text { etc. }\end{array}$ & $\begin{array}{l}\text { AND (LIMIT-TO } \\
\text { (SUBJAREA, "BUSI")) }\end{array}$ & $\mathrm{n}=50$ \\
\hline 5 & $\begin{array}{l}\text { Research } \\
\text { paper keyword } \\
\text { contains "big } \\
\text { data" }\end{array}$ & $\begin{array}{l}\text { To keep only articles which have very } \\
\text { strong indication that area of research is } \\
\text { connected with "big data" since } \\
\text { authors have included these words as } \\
\text { keywords }\end{array}$ & (filtered outside SCOPUS) & $n=37$ \\
\hline 6 & $\begin{array}{l}\text { Authors } \\
\text { excluded } \\
\text { articles not } \\
\text { related to } \\
\text { skills or } \\
\text { competences }\end{array}$ & $\begin{array}{l}\text { After reading abstracts of all articles } \\
\text { authors of this literature review excluded } \\
\text { articles that did not contain information or } \\
\text { were not related to skills or competences } \\
\text { in connection with "big data" }\end{array}$ & (filtered outside SCOPUS) & $\mathrm{n}=21$ \\
\hline
\end{tabular}

Fifth and sixth steps are performed outside SCOPUS database. In fifth step, authors exclude all articles that do not contain keyword "big data". In that way, there are left only articles whose authors have intentionally put "big data" in keywords to indicate connection with this area. After fifth step there are 37 results.

In sixth step, authors read abstracts of selected articles to evaluate if articles are connected with research question. Specifically, if article is connected with big data and contain information about skills or competences in connection with big data. After last step there are 21 articles left. It is a final list of articles used for systematic literature overview.

Overview of performed steps can be seen in Table 1. 


\section{Limitations of research}

There are several available definitions of big data. Different authors indicate different number of attributes that characterize big data; in other words - different number of " $\mathrm{V}$ ". There are definitions that contain starting with $3 \mathrm{~V}$ - volume, velocity, variety (Chen C.P., Zhang C.Y., 2014) and even up to $7 \mathrm{~V}$ - volume, velocity, variety, veracity, value variability, visualization (Seddon J.J., Currie W.L., 2017). Articles included in literature review are not evaluated by the definition of big data - if authors of researches are using the same definition or have the same conceptual understanding of big data.

There is limitation of the research paper field of study - articles are selected only from one field of study - "Business, Management and Accounting".

\section{Characteristics of research papers}

Selected articles split by year of publication are shown in Figure 1. It can be seen that 10 out of 21 articles are published in 2017. This confirms that researchers in the field of Business and Management area only recently have started to focus on the topic.

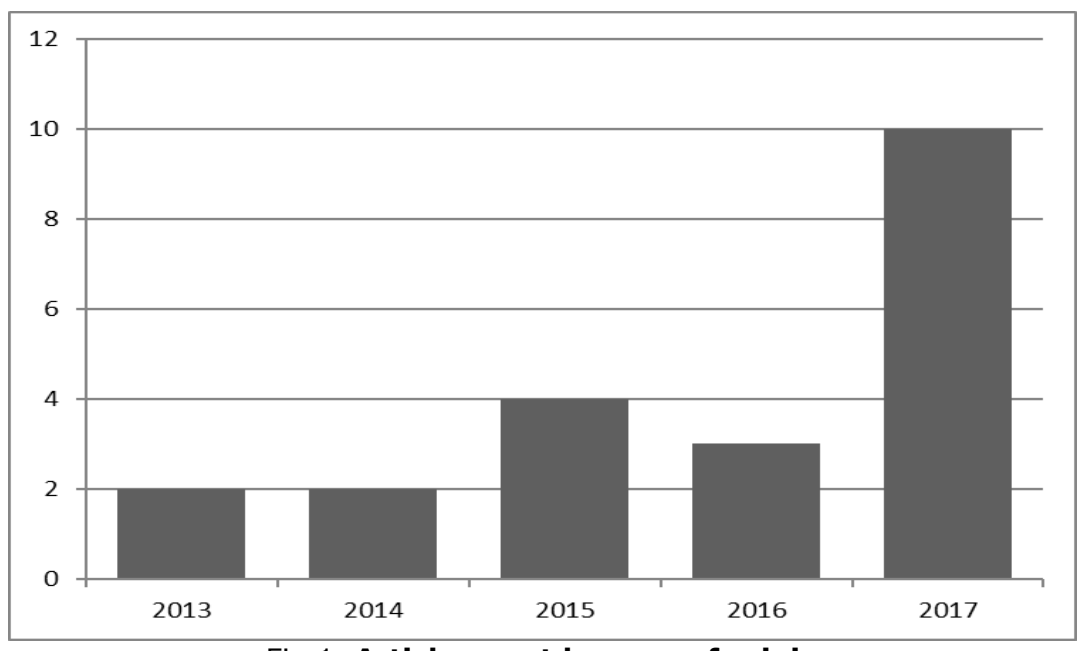

Fig.1. Article count by year of origin

9 out of 21 selected articles are published in 4 journals. Remaining 12 articles are published in separate journals and only one selected article per journals. List of journals having more than 1 article is shown in Table 2.

Journals of publications with more than 1 article

\begin{tabular}{|l|l|l|}
\hline \multicolumn{1}{|c|}{ Journal } & Number of articles & Years of publication \\
\hline Business Process Management Journal & $\mathrm{n}=3$ & $2017 ; 2017 ; 2017$ \\
\hline Business Information Review & $\mathrm{n}=2$ & $2013 ; 2014$ \\
\hline Journal of Accounting Education & $\mathrm{n}=2$ & $2017 ; 2017$ \\
\hline Journal of Business Logistics & $\mathrm{n}=2$ & $2013 ; 2015$ \\
\hline
\end{tabular}

All three articles from Business Process Management Journal are published in 2017. Both articles from Journal of Accounting Education are published also in 2017. At the same time, Business Information Review and Journal of Business Logistics published articles before or during 2015. This indicates that field of Business Logistics started to research area of big data earlier than field of Accounting. 


\section{Skills and competences for big data}

Overview of identified skills and competences are shown in Table 3. Skills and competences are grouped by authors of this research based on common characteristics. Authors as well as year of publication of articles are indicated in the table.

Skill and competence overview

Table 3

\begin{tabular}{|c|c|}
\hline Type of skills and competences & Authors, year of publication \\
\hline General big data skills & $\begin{array}{l}\text { - Hofacker C.F., Malthouse E.C., Sultan F., } 2016 \\
\text { - Murawski M., Bick M., } 2017\end{array}$ \\
\hline General analytical competences & $\begin{array}{l}\text { - Amankwah-Amoah J., } 2015 \\
\text { - Carillo K., } 2017 \\
\text { - Muller S., Jensen P., } 2017 \\
\text { - Tambe P., } 2014 \\
\text { - James R., } 2013 \\
\text { - Waller M.A., Fawcett S.E., } 2013\end{array}$ \\
\hline Advanced analytical competences & $\begin{array}{l}\text { - Alharthi A., Krotov V., Bowman M., } 2017 \\
\text { - Cook D., } 2015 \\
\text { - Gamage P., } 2016 \\
\text { - Martin-Rios C., Pougnet S., Nogareda A.M., } 2017 \\
\text { - Schoenherr T., Speier-Pero C., } 2015\end{array}$ \\
\hline Business competences & $\begin{array}{l}\text { - Alharthi A., Krotov V., Bowman M., } 2017 \\
\text { - Amankwah-Amoah J., } 2015 \\
\text { - Cegielski C.G., Jones-Farmer L.A., } 2016 \\
\text { - Cook D., } 2015 \\
\text { - Dubey R., Gunasekaran A., } 2015 \\
\text { - Frisk J.E., Bannister F., } 2017 \\
\text { - Hackl P., } 2016 \\
\text { - Martin-Rios C., Pougnet S., Nogareda A.M., } 2017 \\
\text { - Schoenherr T., Speier-Pero C., } 2015 \\
\text { - Tambe P., } 2014 \\
\text { - Waller M.A., Fawcett S.E., } 2013\end{array}$ \\
\hline Data management skills & $\begin{array}{l}\text { - Carillo K., } 2017 \\
\text { - Cegielski C.G., Jones-Farmer L.A., } 2016 \\
\text { - James R., } 2014\end{array}$ \\
\hline Technical competences & $\begin{array}{l}\text { - Cook D., } 2015 \\
\text { - Hackl P., } 2016 \\
\text { - Izhar T., Torabi T., Bhatti M.I., } 2016 \\
\text { - Martin-Rios C., Pougnet S., Nogareda A.M., } 2017 \\
\text { - McKinney E. Jr., Yoos C.J., Snead K., } 2017 \\
\text { - Murawski M., Bick M., } 2017 \\
\text { - Tambe P., } 2014 \\
\text { - Yusuf I.I., Thomas I.E., Spichkova M., Schmidt H.W., } 2017\end{array}$ \\
\hline
\end{tabular}

Authors categorized identified skills or competences in 6 broader groups. Each group contains several skills or competences mentioned in analysed articles. First group is General big data skills two articles included in this category. One research paper has mentioned ability to evaluate big data datasets (Hofacker C.F. et. al, 2016). Second research paper indicates general big data skills (Murawski M., Bick M., 2017) without further explanation what can be understood with big data skills. Common characteristic for this group is very general indication of big data skills without specifics.

General analytical competences are second group. 6 out of 21 articles have mentioned analytical competences in different forms - business analytics (Tambe P., 2014), ability to interpret data (James R., 2013) and ability to extract value from data (Muller S., Jensen P., 2017) as well as 
quantitative skills (Waller M.A., Fawcett S.E., 2013) and analytical competences as part of company culture (Carillo K., 2017). Common characteristic for this group is high level analytical competences in different forms.

Advanced analytical competences are third group. Common characteristic for this group is more specific and advanced level analytical skills mentioned in the article in different forms. One article mentions lack of data science skills (Alharthi A., Krotov V., Bowman M., 2017) in the organizations. Complex problem solving skills are mentioned in context of advancements of building and environment professions (Cook D., 2015). One author mentions advanced analytical skills as prerequisite for successful utilization of big data in public sector (Gamage P., 2016).

Business competences are the broadest group. This group contains articles that discuss competences like data driven decision making (Alharthi A., Krotov V., Bowman M., 2017). Since big data solution implementation is associated with costs, then another article also indicates importance of having data driven decision making in the company (Tambe P., 2014). Only one research paper contained information that knowledge of industry is important to succeed in big data usage (Waller M.A., Fawcett S.E., 2013). This group also includes articles that discuss managerial skills that are needed to process changes associated with big data usage (Martin-Rios C., Pougnet S., Nogareda A.M., 2017). Authors have also classified ability to cooperate with other professions (Cook D., 2015) and business units (Amankwah-Amoah J., 2015) as a business competence. One research is aimed at developing master degree programme for predictive analytics (Schoenherr T., Speier-Pero C., 2015). It contains skills and competences starting from advanced analytics and ending with decision making competences.

Data management skills is fifth group, it contains rather technical type of competences and skills - data gathering, interpretation and visualization (Cegielski C.G., Jones-Farmer L.A., 2016). One author indicates a need for multidisciplinary educational programmes in case of big data analytical competences (Carillo K., 2017). Development of technologies and increasing amounts of data drives demand for specialists who can manage and review large datasets (James R., 2014).

Technical competences are mentioned in at least 7 articles. These are competences connected with knowledge of specific software (Izhar T., Torabi T., Bhatti M.I., 2016), (Yusuf I.I., Thomas I.E., Spichkova M., Schmidt H.W., 2017) or broader type of skills like knowledge of databases (Martin-Rios C., Pougnet S., Nogareda A.M., 2017). More than one author points to broad skills like technical competences without detailing what exact skills are needed (Tambe P., 2014) or general digital competences that are not explained in details (Murawski M., Bick M., 2017).

\section{Conclusions, proposals, recommendations}

1) Starting with 2017 there is a huge increase of published research papers related to skills and competences in connection with big data in the fields of Business, Management and Accounting. This indicates that area of research is very new and more researches should come in future.

2) Utilization of big data requires very broad range of different skills and competences. One person will not be able to cover all needs connected with big data solutions. Authors of this research created 6 broad groups of skills and competences discussed in fields of Business, Management and Accounting.

3) There are many articles that refer to very general skills needed for utilization of big data. Skills like big data skills are not self explanatory and one cannot interpret what it is that person should know or be able to perform. 
4) Ability to cooperate and communicate with others is mentioned in at least two articles. Authors emphasize importance of interaction due to nature of big data - very specific IT type of skills are needed to store data, manage software that usually is performed by IT employees. Interpretation and analysis of data is performed by analysts and requires different type of skills while decision making is done by management and requires general understanding of big data and managerial skills. In order to successfully utilize big data, communication between three parties should be done.

5) Authors of this research identified only one article that indicated need for knowledge of industry to successfully utilize big data. Authors recommend to research this area further to evaluate if big data skills and competences can be successfully transferred between industries or they must be adapted in any way for each specific industry.

\section{Bibliography}

1. Alharthi, A., Krotov, V. and Bowman, M., 2017. Addressing Barriers to Big Data. Business Horizons, 60(3), pp.285-292.

2. Amankwah-Amoah, J., 2015. Safety or No Safety in Numbers? Governments, Big Data and Public Policy Formulation. Industrial Management \& Data Systems, 115(9), pp.1596-1603.

3. Big data: The Next Frontier for Innovation, Competition, and Productivity (McKinsey Global Institute) (2011). Retrieved: https://www.mckinsey.com/business-functions/digital-mckinsey/our-insights/big-datathe-next-frontier-for-innovation Access: 19.12.2017.

4. Booth, A., Sutton, A., \& Papaioannou, D. 2012. Systematic Approaches to a Successful Literature Review.

5. Carillo, K., 2017. Let's Stop Trying to be "Sexy"-Preparing Managers for the (Big) Data-Driven Business Era. Business Process Management Journal, 23(3), pp.598-622.

6. Cegielski, C. and Jones- Farmer, L., 2016. Knowledge, Skills, and Abilities for Entry- Level Business Analytics Positions: A Multi- Method Study. Decision Sciences Journal of Innovative Education, 14(1), pp.91-118.

7. Chen, C.P. and Zhang, C.Y., 2014. Data-Intensive Applications, Challenges, Techniques and Technologies: A Survey on Big Data. Information Sciences, 275, pp.314-347.

8. Cook, D., 2015. RICS Futures: Turning Disruption from Technology to Opportunity. Journal of Property Investment \& Finance, 33(5), pp.456-464.

9. Dubey, R. and Gunasekaran, A., 2015. Education and Training for Successful Career in Big Data and Business Analytics. Industrial and Commercial Training, 47(4), pp.174-181.

10. Frisk, J.E. and Bannister, F., 2017. Improving the Use of Analytics and Big Data by Changing the DecisionMaking Culture: A Design Approach. Management Decision, 55(10), pp.2074-2088.

11. Gamage, P., 2016. New Development: Leveraging 'Big Data' Analytics in the Public Sector. Public Money \& Management, 36(5), pp.385-390.

12. Hackl, P., 2016. Big Data: What Can Official Statistics Expect?. Statistical Journal of the IAOS, 32(1), pp.4352.

13. Hofacker, C.F., Malthouse, E.C. and Sultan, F., 2016. Big Data and Consumer Behavior: Imminent Opportunities. Journal of Consumer Marketing, 33(2), pp.89-97.

14. Izhar, T.A.T., Torabi, T. and Bhatti, M.I., 2017. Using Ontology to Incorporate Social Media Data and Organizational Data for Efficient Decision-Making. International Journal of Computer Information Systems and Industrial Management Applications, 9(2017), pp.9-22.

15. James, R., 2013. Out of the Box: Information Morality-Reasonable Doubt. Business Information Review, 30(1), pp.35-39.

16. James, R., 2014. Out of the box: Big Data Needs the Information Profession-the Importance of Validation. Business Information Review, 31(2), pp.118-121.

17. Martin-Rios, C., Pougnet, S. and Nogareda, A.M., 2017. Teaching HRM in Contemporary Hospitality Management: a Case Study Drawing on HR Analytics and Big Data Analysis. Journal of Teaching in Travel \& Tourism, 17(1), pp.34-54.

18. McKinney Jr, E., Yoos, C. and Snead, K., 2017. The Need for 'Skeptical' Accountants in the Era of Big Data. Journal of Accounting Education, 38, pp.63-80.

19. Muller, S. and Jensen, P., 2017. Big Data in the Danish Industry: Application and Value Creation. Business Process Management Journal, 23(3), pp.645-670.

20. Murawski, M. and Bick, M., 2017. Digital Competences of the Workforce-a Research Topic?. Business Process Management Journal, 23(3), pp.721-734.

21. Schoenherr, T. and Speier- Pero, C., 2015. Data Science, Predictive Analytics, and Big Data in Supply Chain Management: Current State and Future Potential. Journal of Business Logistics, 36(1), pp.120-132. 
22. Seddon, J.J. and Currie, W.L., 2017. A Model for Unpacking Big Data Analytics in High-Frequency Trading. Journal of Business Research, 70, pp.300-307.

23. Tambe, P., 2014. Big Data Investment, Skills, and Firm Value. Management Science, 60(6), pp.1452-1469.

24. Waller, M. and Fawcett, S., 2013. Data Science, Predictive Analytics, and Big Data: a Revolution That Will Transform Supply Chain Design and Management. Journal of Business Logistics, 34(2), pp.77-84.

25. Yusuf, I., Thomas, I., Spichkova, M. and Schmidt, H., 2017. Chiminey: Connecting Scientists to HPC, Cloud and Big Data. Big Data Research, 8, pp.39-49. 